\title{
HYDRAULIC CONDUCTIVITY AND SOIL-SEWAGE SLUDGE INTERACTIONS ${ }^{(1)}$
}

\author{
Silvio Romero de Melo Ferreira ${ }^{(2)}$, Joaquim Teodoro Romão de \\ Oliveira $^{(2)}$, Arminda Saconi Messias ${ }^{(2,3)}$, Hannelore Alves e Silva ${ }^{(4)}$, \\ Aline Elesbão do Nascimento ${ }^{(2)} \&$ Maria Célia Alves Feitosa ${ }^{(2)}$
}

\begin{abstract}
One of the main problems faced by humanity is pollution caused by residues resulting from the production and use of goods, e.g, sewage sludge. Among the various alternatives for its disposal, the agricultural use seems promising. The purpose of this study was to evaluate the hydraulic conductivity and interaction of soil with sandy-silty texture, classified as Spodosols, from the Experimental Station Itapirema - IPA, in Goiana, state of Pernambuco, in mixtures with sewage sludge from the Mangueira Sewage Treatment Station, in the city of Recife, Pernambuco at rates of 25,50 and $75 \mathrm{Mg} \mathrm{ha}^{-1}$. Tests were conducted to let water percolate the natural saturated soil and soil-sludge mixtures to characterize their physical, chemical, and microstructural properties as well as hydraulic conductivity. Statistical data analysis showed that the presence of sewage sludge in soils leads to an increase of the $<0.005 \mathrm{~mm}$ fraction, reduction in real specific weight and variation in optimum moisture content from 11.60 to $12.90 \%$ and apparent specific dry weight from 17.10 and $17.50 \mathrm{kN} \mathrm{m}^{-3}$. In the sludge-soil mixture, the quartz grains were covered by sludge and filling of the empty soil macropores between grains. There were changes in the chemical characteristics of soil and effluent due to sewage sludge addition and a small decrease in hydraulic conductivity. The results indicate the possibility that soil acidity influenced the concentrations of the elements found in the leachate, showing higher levels at higher sludge doses. It can be concluded that the leaching degree of potentially toxic elements from the sewage sludge treatments does not harm the environment.
\end{abstract}

Index terms: solid waste, soil physical and chemical properties, environment.

\footnotetext{
(1) Received for publication in November 23, 2010 and approved in July 27, 2011.

(2) Professores de programas de pós-graduação da Universidade Católica de Pernambuco - UNICAP. Rua do Príncipe 526, Boa Vista, Bloco D, CEP 50050-900 Recife (PE), Brasil. E-mails: sr.mf@hotmail.com; jtrdo@uol.com.br; elesbão@unicap.br; célia@unicap.br

(3) Pesquisadora do Instituto Agronômico de Pernambuco - IPA. Recife (PE), Brasil. E-mail: saconi@unicap.br

(4) Engenheira Ambiental da Termoaçu S/A. Rua Joaquim Fabrício 709, Petrópolis, Natal (RN), Brasil. E-mail: hanneas@hotmail.com
} 


\title{
RESUMO: CONDUTIVIDADE HIDRÁULICA E INTERAÇÕES SOLO-LODO DE ESGOTO
}

\begin{abstract}
Um dos principais problemas enfrentados pela humanidade é a poluição causada por resíduos gerados na fabricação e utilização de bens, entre eles o lodo de esgoto. Entre as diversas alternativas para a disposição do lodo de esgoto tratado, a utilização agrícola apresentase como promissora. Este trabalho teve como objetivo avaliar a condutividade hidráulica e a interação de um solo de textura arenossiltoso, classificado como Espodossolo, proveniente da Estação Experimental de Itapirema/IPA, município de Goiana/PE, misturado com lodo de esgoto coletado da ETE Mangueira, Recife/PE, nas doses equivalentes a 25, 50 e $75 \mathrm{Mg} \mathrm{ha}^{-1}$. Foram realizados ensaios de caracterizações físicas, químicas, microestruturais e da condutividade hidráulica do solo natural saturado e nas misturas solo-lodo quando percolado por água. Após a análise estatística dos dados, percebeu-se que a presença de lodo de esgoto nos solos provoca acréscimo na fração menor que 0,005 $\mathrm{mm}$, diminuição no peso específico real, variação na umidade ótima de 11,60 a 12,90 \% e do peso específico aparente de amostra seca entre 17,10 e 17,50 $\mathrm{kN} \mathrm{m}^{-3}$. Na mistura solo-lodo houve o revestimento dos grãos de quartzo pelo lodo e preenchimento dos macroporos do solo deixados entre os grãos. Houve modificações nas características químicas do solo e do efluente com o acréscimo de lodo ao solo e pequena diminuição da condutividade hidráulica. Observou-se nos lixiviados que, possivelmente, a acidez do solo influenciou no aumento das concentrações dos elementos encontrados, apresentando maiores teores nas doses de lodo de esgoto mais altas. Conclui-se que o grau de lixiviação de elementos químicos potencialmente tóxicos provenientes dos tratamentos com lodo de esgoto não causa danos ao meio ambiente.
\end{abstract}

Termos de indexação: resíduos sólidos, atributos físico-químicos do solo, meio ambiente.

\section{INTRODUCTION}

Solid waste, liquid and gas generated by the production and use of goods and released to the environment are causing serious environmental problems. The largest waste volume originates from domestic waste and sewage treatment. Sewage sludge is a generic name for solid waste generated by wastewater treatment systems. It may contain undesirable chemical and biological elements from an environmental point of view. Among sewage sludge pollutants, chemical contaminants (potentially toxic elements) are the largest group and should be constantly monitored, due to the contamination risks for humans, animals and plants.

Any decision on the most appropriate final destination for sewage sludge should be based on the evaluation and minimization of contamination risks to the environment and to human beings. When the physical and chemical characteristics of sewage sludge are known and the presence or absence of contaminants detected, it is possible to study efficient disposal alternatives by which environmental risks and economic losses can be minimized. Among the various alternatives for sewage sludge disposal, it seems that the most convenient and promising, especially from the economic point of view, is the agricultural use, since the sludge contains considerable levels of organic matter and nutrients (Santos, 2003; Barboza, 2007; Silva, 2008; Lopes, 2008).
Among the effects of sewage sludge on soil physical properties, mainly due to the presence of organic matter, the improvement in particle aggregation, with consequent decrease in density and increase in aeration and water retention can be highlighted (Melo $\&$ Marques, 2000). Concerning the chemical aspects, the sludge application in soil has resulted in elevated levels of P (Silva et al., 2002), organic C (Carvallaro et al., 1993), and humic fraction of organic matter (Melo et al., 1994), pH, electrical conductivity and cation exchange capacity (Oliveira et al., 2002).

The presence of heavy metals is one of the major limitations to the use of sewage sludge in agriculture. In general, metal concentrations found in sludge are much higher than those found naturally in soil, indicating the urgent need for risk assessment associated with the increase of these elements in the environment by the application of this waste.

The downward vertical movement of contaminants in the soil profile can represent a great problem for contemporary society, in vies of the growing interest in the use of municipal waste in agriculture (Oliveira $\&$ Mattiazzo, 2001). This topic has received increased attention from researchers in recent years, especially with regard to heavy metal mobility (Melo et al., 1994; Oliveira \& Mattiazzo, 2001; Oliveira et al., 2002; Lopes, 2008; Teixeira et al, 2010a).

Although the soil is a natural protection barrier of underground aquifers, the factors that govern the ability to retain potentially toxic elements are 
extremely complex, which considerably complicates the understanding and possibilities of predictions about the behavior of these elements, especially in the long term. It is known that the greater or lower mobility of heavy metals is determined by soil characteristics such as original metal content, texture, levels and clay types, pH, CEC, organic matter content and others, that influence reactions of adsorption / desorption, precipitation / dissolution, complexation and oxireduction (Oliveira \& Mattiazzo, 2001).

The objectives of this study were to analyze hydraulic conductivity and soil-sludge interaction on the soil physical-chemical and microstructural properties for the use of sewage sludge in agriculture.

\section{MATERIAL AND METHODS}

Sewage sludge was sampled from the tank of aerobic digestion at the Mangueira sewage treatment station, in Recife, Pernambuco. The material was air-dried, ground and sieved through $4.8 \mathrm{~mm}$ mesh. Sludge granulometry was evaluated following the recommendations of $\mathrm{ABNT}$ (1984a) and the moisture was determined by drying to constant weight at $45^{\circ} \mathrm{C}$ with consecutive weighing every $24 \mathrm{~h}$.

The soil used in the experiments was classified as Spodosol, collected from the 0-0.20 m layer by a conventional auger, at the Experimental Station of Itapirema / IPA in Goiana, Pernambuco. The sample was air-dried, homogenized and sieved through $4.8 \mathrm{~mm}$ mesh. Natural soil and three mixtures of soil with sludge, equivalent to $25,50,75 \mathrm{Mg} \mathrm{ha}^{-1}$, were physically characterized, according to the methods of the Brazilian Association of Technical Standards: (ABNT, 1984a,b,c,d; ABNT, 1986b). In the experiment for mobility of chemical elements, PVC tubes (diameter $0.10 \mathrm{~m}$ ) were used for natural soil samples (height $0.21 \mathrm{~m}$ ) and soil-sludge mixtures equivalent to $25,50,75 \mathrm{Mg} \mathrm{ha}^{-1}$ were placed, 3 per sample, totaling 12 columns (Figure 1). The sludge was mixed with the soil in the top $50 \mathrm{~mm}$, simulating the position of the residue on the field surface. To each column, deionized water was applied relative to the soil field capacity daily for 60 days, and the effluent collected fortnightly at the column basis for complete chemical analysis (Embrapa, 1997). After 60 days, the same amount of water was applied for 5 consecutive days and the amount of effluent was quantified in a measuring cylinder. After completion of the tests, the natural moisture of soil and sludge-soil mixtures were determined at the top and bottom of each column, evaluating the size, height and diameter at eight different points of each sample in columns to determine the sample volume and wet weight. For data analysis of changes in the composition of micronutrients and cadmium after 60 days and the soil after leaching principal component analysis - PCA was used (Jolliffe, 2002).

The microstructure of soil and of soil-sludge mixtures was observed in samples collected from the top and bottom of the columns after the experiments testing the mobility of chemical elements. The samples were removed carefully, air -dried, and three cylindrical samples (diameter $9.8 \mathrm{~mm}$, height $8 \mathrm{~mm}$ ) were used in the study (Ferreira, 1995). The specimens were mounted on $\mathrm{Al}$ stubs (diameter $9.8 \mathrm{~mm}$, height $11 \mathrm{~mm}$ ), using $3 \mathrm{M}$ tape. The samples were subjected to metallization in a JEOL Fine Coat Ion Sputter JFC 1100, sputter-coated with gold, standard for sputtering, easy to coat, inert, stable under electron beam. After the metallization process, the samples surfaces were observed and photographed in a Scanning Electron Microscope, JSM LV1600, at 15 Kv. A comparative analysis of electron micrographs was performed.

The saturated hydraulic conductivity of soil samples from natural and sludge-soil mixtures was determined using flexible wall permeameter. The specimens had an average height of $109 \mathrm{~mm}$ and average diameter of $98 \mathrm{~mm}$. They were cast statically and under the same conditions of average moisture and average dry unit weight of test samples of the columns of the experiment mobility of chemical elements. The cell samples were placed in contact with filter paper and porous stone on top, bottom, and a membrane-coated latex protection. The water saturation of the samples was almost immediate. After saturation, confining stresses of 0, 15, 25, 50, $75,100,150,200 \mathrm{kPa}$, were applied in stages. Between each stage and after consolidation the saturated hydraulic conductivity was determined by applying a voltage difference of $5 \mathrm{kPa}$ between the top and bottom of the samples and the time required for a volume of $5000 \mathrm{~mm}^{3}$ of water to pass through the sample was determined. The process was repeated until three consecutive intervals of equal time were obtained.

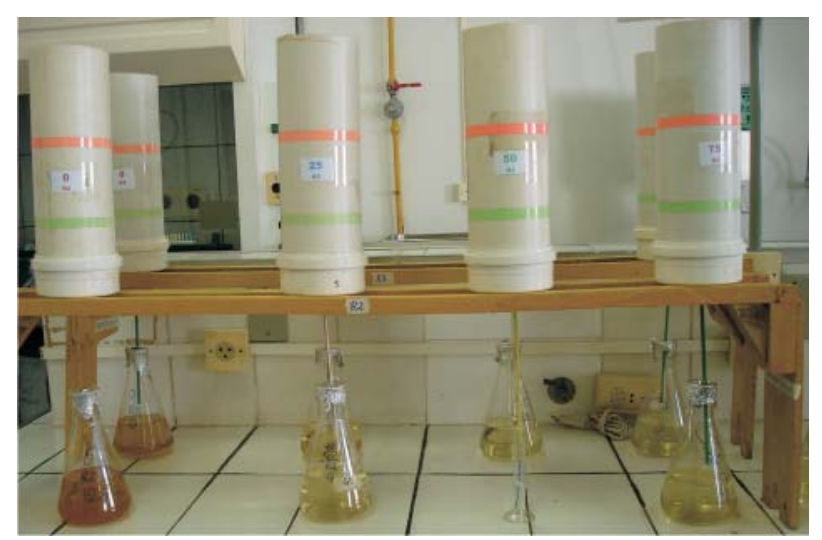

Figure 1. PVC columns with samples of natural soil and soil-sludge mixtures. 


\section{RESULTS AND DISCUSSION}

\section{Physical characterization of soil, sludge and sludge-soil mixtures}

The natural soil is a silty-sand (SM) according to the Unified classification. Due to the large amount of sand in the soil, it was not possible to obtain values of soil moisture corresponding to the limits of liquidity and plasticity. The real specific weight of grains is equal to $26 \mathrm{kN} \mathrm{m}^{-3}$ and has as $11.90 \%$ optimum moisture and maximum apparent dry specific weight of $17.60 \mathrm{kN} \mathrm{m}^{-3}$ (Table 1).

The sludge was composed of $82 \%$ granules (size between $4.8 \mathrm{~mm}$ and $0.1 \mathrm{~mm}$ ) and $12 \%<0.1 \mathrm{~mm}$. The granulometric curve of the sludge is similar to that of natural soil (Figure 2).

Soil mixtures with sewage sludge were also classified as silty-sand (SM), non-liquid and nonplastic. However, sewage sludge application to the soil increased particles $<0.005 \mathrm{~mm}$, from $4 \%$ in the natural soil to values of $30 \%$ in the sludge-soil mixture. The real specific weight of grains in the soil-sludge decreased $\left(25 \mathrm{kN} \mathrm{m}^{-3}\right)$, the optimum water ratio ranged from $11.60 \%$ to $12.90 \%$ and maximum apparent dry specific weight was between 17.10 and $17.50 \mathrm{kN} \mathrm{m}^{-3}$ (Figure 3). It was noted that these soil indices are little altered by sewage sludge mixtures, compared to natural soil.
In the experiment for chemical element mobility the natural soil moisture was higher at the bottom of the column than at the top. The water used was retained in the upper $0.10 \mathrm{~m}$ of soil, (Figure 4a). As sludge was added to the soil, water was stored at the surface (top) in increasing amounts, as sludge amount augmented. Mud increase the soil capacity to retain water on the surface (Figure 4a), in accordance with Melo \& Marques (2000) and increases the water saturation degree (Figure 4b), as well as the void (Figure 4c) and porosity indexes; and decreases the wet specific and apparent dry weight (Figure 4d). These aspects are fundamental for the development of plant roots.

\section{Microstructural soil analysis}

Electronmicrographs of soil, sludge and sludge-soil mixtures are shown in figure 5 . The soil matrix consists of an intense amount of sand grains and little clay. The sand grains consist almost entirely of quartz, with varying sizes and predominantly round shape and low intensity of angular forms (Figure 5a). There is a small amount of mostly mineral (clay) plasma, partially covering the skeleton grains (sand), often not extending to form bridges among them. This texture tends to the predominant formation of a porosity type called Simple Packaging Pores (Brewer, 1976), i.e, empty spaces are results of the junction of particles with different sizes and shapes.

Table 1. Physical indices in soil and soil plus sewage sludge

\begin{tabular}{|c|c|c|c|c|c|c|}
\hline Material & Real specific weight & Sand & Silt & Clay & $\begin{array}{c}\text { Optimum } \\
\text { water ratio }\end{array}$ & $\begin{array}{l}\text { Maximum apparent dry } \\
\text { specific weight }\end{array}$ \\
\hline & $\mathrm{kN} \mathrm{m}^{-3}$ & 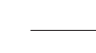 & 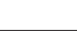 & $-\%-$ & - & $\mathrm{kN} \mathrm{m}^{-3}$ \\
\hline Natural soil & 26 & 92 & 4 & 4 & 11.90 & 17.60 \\
\hline Soil: sludge, $25 \mathrm{Mg} \mathrm{ha}^{-1}$ & 25 & 65 & 9 & 26 & 11.80 & 17.10 \\
\hline Soil: sludge, $50 \mathrm{Mg} \mathrm{ha}^{-1}$ & 25 & 71 & 4 & 25 & 11.60 & 17.50 \\
\hline Soil: sludge, $75 \mathrm{Mg} \mathrm{ha}^{-1}$ & 25 & 66 & 4 & 30 & 12.90 & 17.50 \\
\hline
\end{tabular}

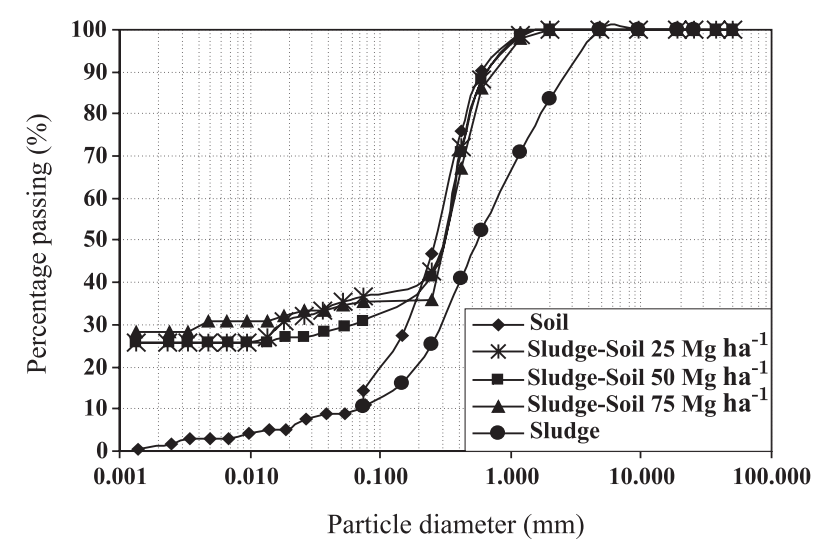

Figure 2. Granulometric curves - natural soil, sludge and sludge-soil mixtures $\left(0,25,50,75 \mathrm{Mg} \mathrm{ha}^{-1}\right.$ and sludge only).

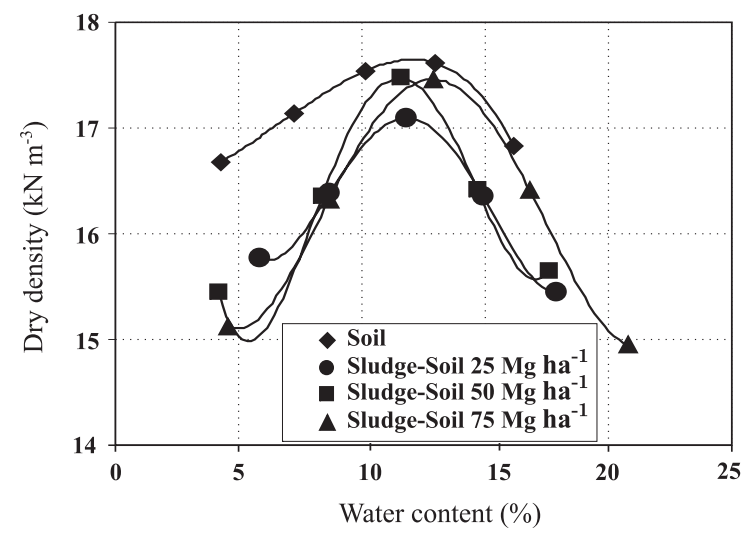

Figure 3. Compression curves - natural soil and sludge-soil mixtures $\left(0,25,50\right.$ and $\left.75 \mathrm{Mg} \mathrm{ha}^{-1}\right)$. 
The sludge is composed by particles of different shapes connected between them and fibers (Figure 5b). If the amount of sludge in natural soil increases, sand grains are gradually covered by sewage sludge reducing the direct contacts among quartz grains (Figure 5c, d and e).
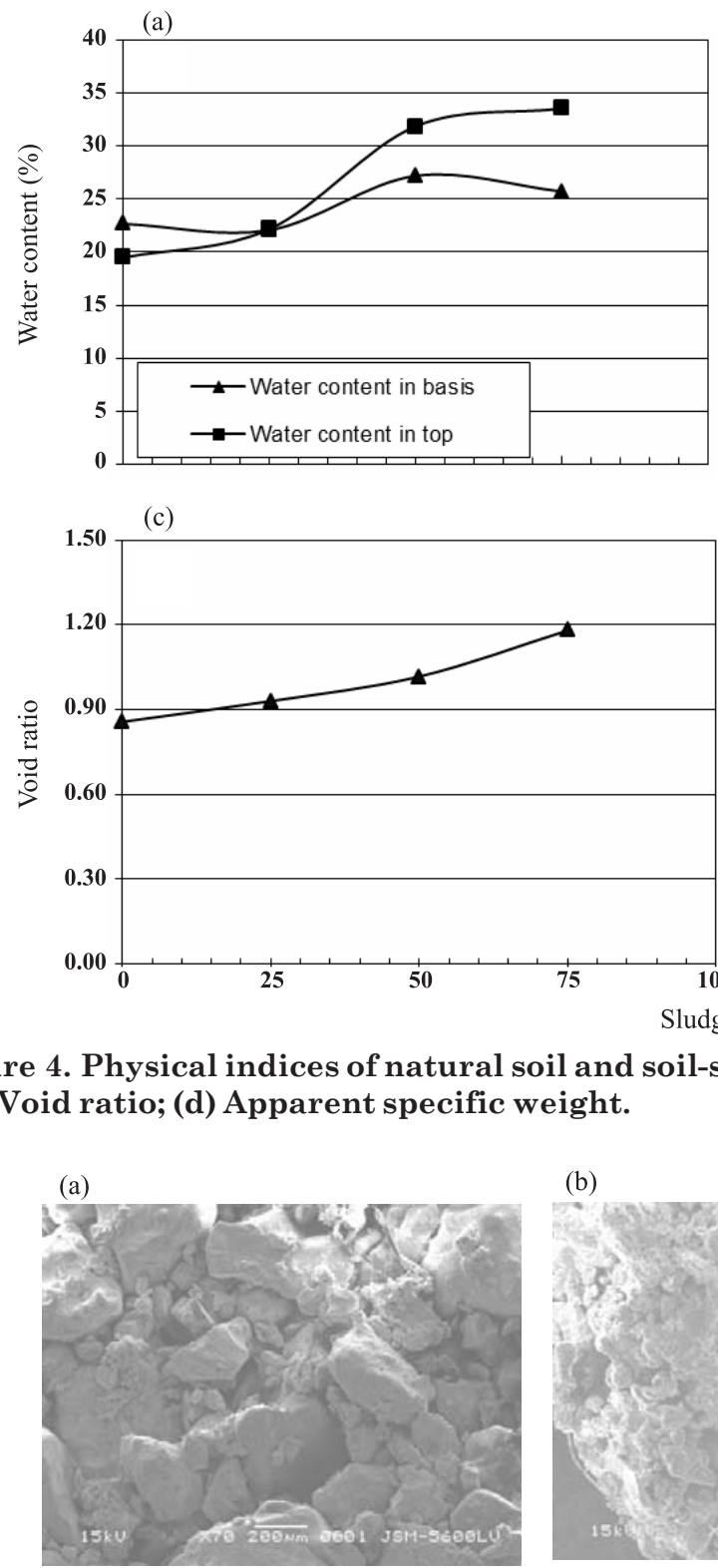

\section{Void ratio; (d) Apparent specific weight.}

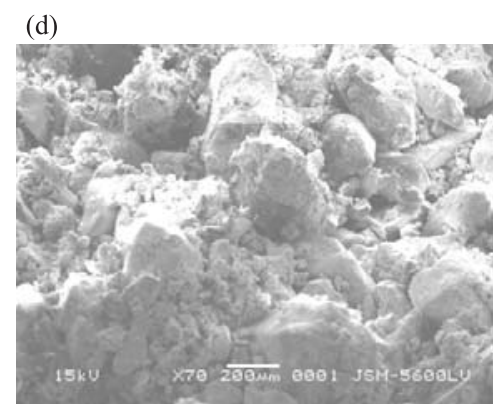

\section{Chemical analysis}

In the natural soil, cation exchange capacity was low $\left(\mathrm{CEC}=5.7 \mathrm{cmol}_{\mathrm{c}} \mathrm{dm}^{-3}\right)$ with low activity (Ta), typical of mineral-clay kaolinite. Base-saturation expressed in percentage ( $\mathrm{V}=56.32 \%)$ was above $50 \%$,

(b)
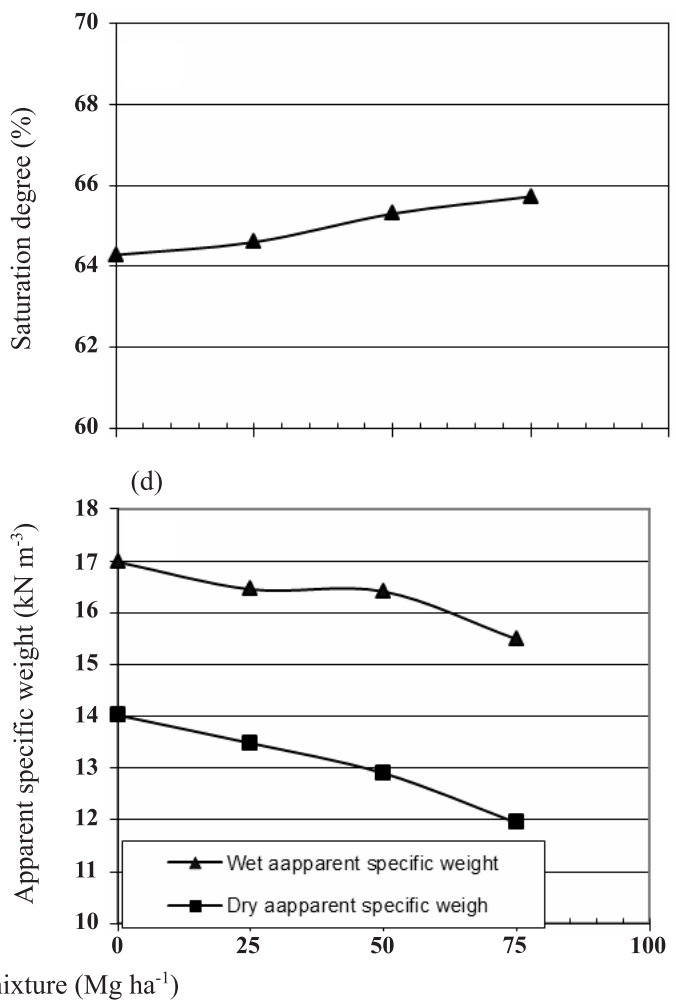

Figure 4. Physical indices of natural soil and soil-sludge mixture (a) Water ratio; (b) Saturation degree; (c)

(b)

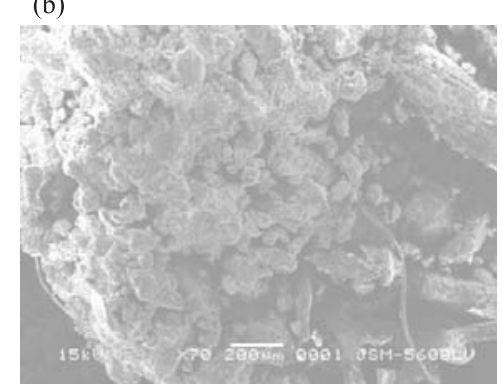

(e)

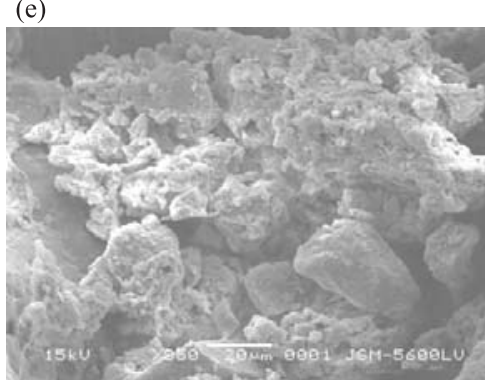

(c)

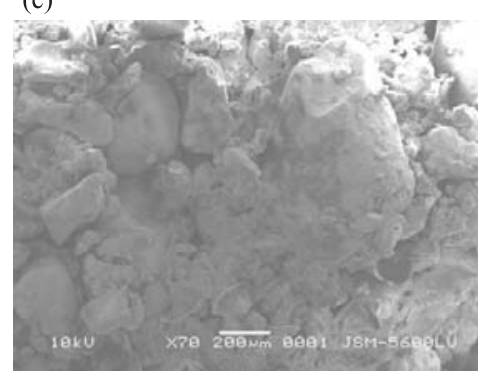

(a) Soil

(b) Sludge

(c) Sludge-Soil $\left(25 \mathrm{Mg} \mathrm{ha}^{-1}\right)$

(d) Sludge-Soil (50 $\left.\mathrm{Mg} \mathrm{ha}^{-1}\right)$

(e) Sludge-Soil (75 $\left.\mathrm{Mg} \mathrm{ha}^{-1}\right)$

Figure 5. Electronmicrographs of the contexture of soil, sludge and sludge-soil mixtures. 
representing an Eutrophic soil (fertile soil and with nutrient reserves for plants). The $\mathrm{pH}$ determined in water was acid $(\mathrm{pH}<7)$. The amount of organic matter obtained from organic carbon was $2.4 \%$.

Test results for chemical characterization of soil, sludge and sludge-soil mixture in rates of zero, 25,50 and $75 \mathrm{Mg} \mathrm{ha}{ }^{-1}$ collected after 60 days of leaching, divided into top $(0-0.10 \mathrm{~m})$ and bottom layer $(0.10-$ $0.20 \mathrm{~m}$ ) are presented in table 2 . Results related to the physical aspects and heavy metal contents are shown in table 3.

Sludge application to the soil resulted in an increase in levels of $\mathrm{P}, \mathrm{K}, \mathrm{Na}, \mathrm{Mg}$, and $\mathrm{Al}$, which were highest in the top samples. Nitrogen had an opposite pattern, with higher concentrations at the base, lower than in natural soil. The rate of $25 \mathrm{Mg} \mathrm{ha}^{-1}$ was not significantly different for $\mathrm{K}$ and $\mathrm{Mg}$ in the top and bottom samples. The $\mathrm{P}$ content found in soil was considered low, but increased by sludge application, as also observed by Silva at al. (2002). According to Tomé Jr. (1997), regardless of the soil, P levels will be considered low when under $3 \mathrm{mg} \mathrm{kg}^{-1}$, and higher when above $30 \mathrm{mg} \mathrm{kg}^{-1}$. Teixeira et al. (2010a,b) examined the leachate from a clayey Oxisol from the city of Londrina and found changes in soil chemical characteristics. They observed impregnation of substances leached from the soil pores by optical microscopy.

It can be observed that the $\mathrm{pH}$ at the column top was lower than at the base (Table 3). Both values decreased with sludge application at the doses studied and sank below the natural soil $\mathrm{pH}$, with exception of the dose corresponding to $25 \mathrm{Mg} \mathrm{ha}^{-1}$. Values of EC, $\mathrm{Cu}^{2+}, \mathrm{Zn}^{2+}$, and $\mathrm{Fe}^{2+}$ increased at the column top with increasing doses compared to the base. These values, however, were lowest than those determined for the natural soil. Exceptions were noted for EC values at

Table 2. Chemical characterization of the soil, sludge and sludge-soil mixture after sampling

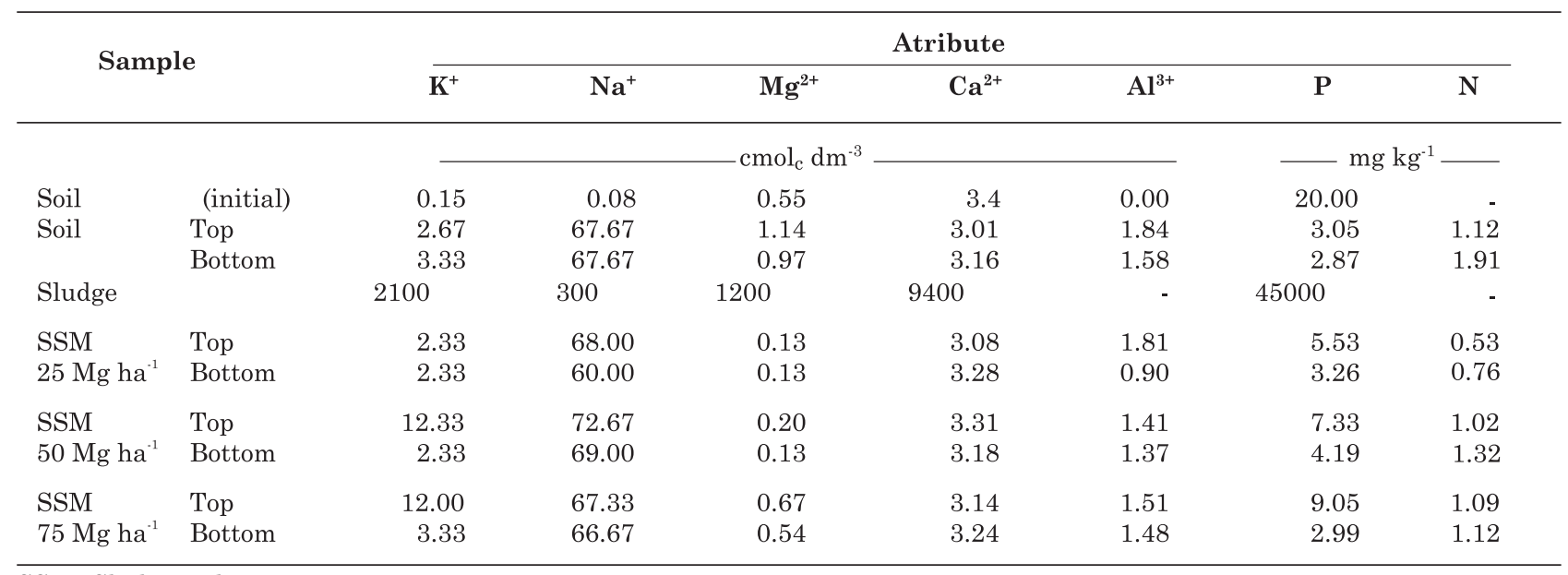

SSM: Sludge-soil mixture.

Table 3. Values of $\mathrm{pH}$, electrical conductivity (EC), $\mathrm{Cu}^{2+}, \mathrm{Zn}^{2+}, \mathrm{Fe}^{2+}$, and $\mathrm{Cd}^{2+}$ at the top and bottom of columns of soil and soil-sludge mixtures

\begin{tabular}{|c|c|c|c|c|c|c|}
\hline \multirow{2}{*}{\multicolumn{2}{|c|}{ Determination }} & \multirow{2}{*}{ Soil (beginning) } & \multirow{2}{*}{ Soil (end) } & \multicolumn{3}{|c|}{ Soil + Sludge mixture $\left(\mathrm{Mg} \mathrm{ha}^{-1}\right)$} \\
\hline & & & & 25 & 50 & 75 \\
\hline $\begin{array}{l}\mathrm{pH} \\
\text { water 1:2.5 }\end{array}$ & $\begin{array}{l}\text { Top } \\
\text { Bottom }\end{array}$ & 6.3 & $\begin{array}{l}5.85 \\
6.13\end{array}$ & $\begin{array}{l}6.05 \\
6.30\end{array}$ & $\begin{array}{l}5.56 \\
5.61\end{array}$ & $\begin{array}{l}5.09 \\
5.31\end{array}$ \\
\hline $\begin{array}{l}\mathrm{EC} \\
\left(\mu \mathrm{S} \mathrm{cm}^{-1}\right)\end{array}$ & $\begin{array}{l}\text { Top } \\
\text { Bottom }\end{array}$ & - & $\begin{array}{r}9.80 \\
10.43\end{array}$ & $\begin{array}{r}33.9 \\
25.37\end{array}$ & $\begin{array}{l}52.97 \\
45.57\end{array}$ & $\begin{array}{l}77.23 \\
69.77\end{array}$ \\
\hline $\begin{array}{l}\mathrm{Cu}^{2+} \\
\left(\mathrm{mg} \mathrm{mL}^{-1}\right)\end{array}$ & $\begin{array}{l}\text { Top } \\
\text { Bottom }\end{array}$ & 1.5 & $\begin{array}{l}0.15 \\
0.22\end{array}$ & $\begin{array}{l}0.31 \\
0.10\end{array}$ & $\begin{array}{l}0.28 \\
0.22\end{array}$ & $\begin{array}{l}0.30 \\
0.23\end{array}$ \\
\hline $\begin{array}{l}\mathrm{Zn}^{2+} \\
\left(\mathrm{mg} \mathrm{mL}^{-1}\right)\end{array}$ & $\begin{array}{l}\text { Top } \\
\text { Bottom }\end{array}$ & 1.8 & $\begin{array}{l}0.83 \\
0.52\end{array}$ & $\begin{array}{l}0.90 \\
0.37\end{array}$ & $\begin{array}{l}1.50 \\
0.49\end{array}$ & $\begin{array}{l}1.58 \\
0.45\end{array}$ \\
\hline $\begin{array}{l}\mathrm{Fe}^{2+} \\
\left(\mathrm{mg} \mathrm{mL}^{-1}\right)\end{array}$ & $\begin{array}{l}\text { Top } \\
\text { Bottom }\end{array}$ & 160 & $\begin{array}{l}26.63 \\
30.44\end{array}$ & $\begin{array}{l}28.75 \\
24.56\end{array}$ & $\begin{array}{l}28.96 \\
23.74\end{array}$ & $\begin{array}{l}37.23 \\
23.76\end{array}$ \\
\hline $\begin{array}{l}\mathrm{Cd}^{2+} \\
\left(\mathrm{mg} \mathrm{mL}^{-1}\right)\end{array}$ & $\begin{array}{l}\text { Topo } \\
\text { Bottom }\end{array}$ & - & $\begin{array}{l}0.18 \\
0.01\end{array}$ & $\begin{array}{l}0.02 \\
0.02\end{array}$ & $\begin{array}{l}0.08 \\
0.10\end{array}$ & $\begin{array}{l}0.18 \\
0.02\end{array}$ \\
\hline
\end{tabular}


the end of the experiment, where the base value was higher, and for $\mathrm{Cd}^{2+}$ which varied according to the dose applied.

Highest metal concentrations were found in the top samples. Retention of these metals was observed in the top soil centimeters, at concentrations of 25,50 and $75 \mathrm{Mg} \mathrm{ha}^{-1}$ compared to the natural soil. There was also a contrast between $\mathrm{pH}$ and $\mathrm{EC}$ and a direct correlation between EC and the metal concentration studied. This fact showed an increase of availability metal elements at the lowest $\mathrm{pH}$ values.

In the effluent (Table 4) the $\mathrm{pH}$ decreased in relation to the sampling period, and increased with increasing doses. The increase in EC values indicates a possible increased availability of certain chemical elements. The results demonstrated that $\mathrm{P}, \mathrm{Na}^{+}$, $\mathrm{Cu}^{2+}, \mathrm{Zn}^{2+}, \mathrm{Fe}^{2+}$, and $\mathrm{Cd}^{2+}$ in the effluents were present in the top soil (Tables 2 and 3), which represented the possibility of sorptive reactions occurring in the surface horizon, and minimize the possibility of subsurface horizon contamination.

\section{Hydraulic conductivity}

The average value of hydraulic conductivity of saturated natural soil was $3.6 \times 10^{-5} \mathrm{~m} \mathrm{~s}^{-1}$, typical value for sandy soil. Similar results were obtained by Oliveira et al. (2009) for sandy soil. An increase of confining stress to $200 \mathrm{kPa}$ caused a reduction of hydraulic conductivity to $2.0 \times 10^{-5} \mathrm{~m} \mathrm{~s}^{-1}$ (Figure 6).

Sewage sludge doses increasing from $25 \mathrm{Mg} \mathrm{ha}^{-1}$ to $75 \mathrm{Mg} \mathrm{ha}^{-1}$ caused a decrease in dry density and wet unit weight mixtures (Figure 3d). As the initial

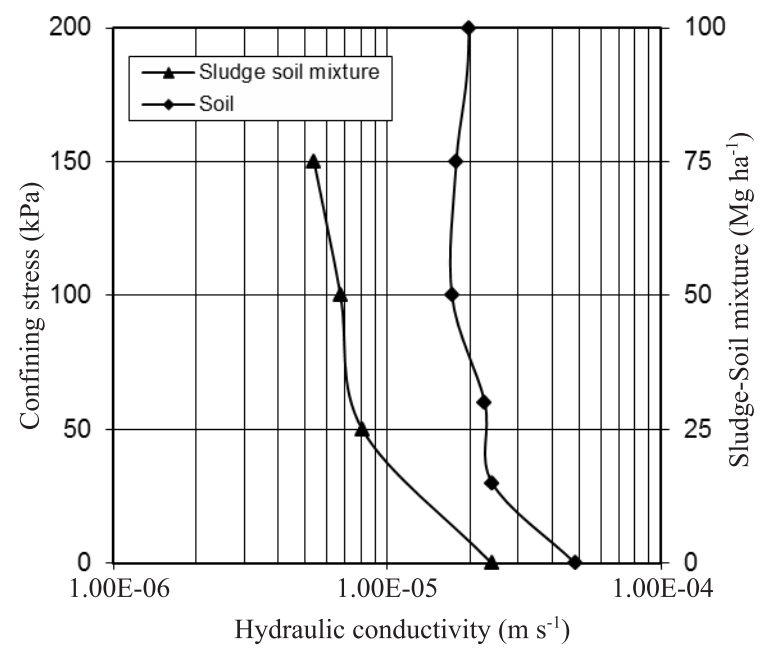

Figure 6. Hydraulic conductivity of soil and sludgesoil mixtures.

sample volume was the same, there was a greater amount of sludge particles in the mixtures with increasing doses, especially for the fractions $<0.1 \mathrm{~mm}$ (Figure 2). The electronmicrographs (Figure 5) showed that there was also a greater amount of smaller sludge particles, covering the quartz grains, which reduced the pore sizes of the soil-sludge mixture and induced a reduction in hydraulic conductivity of soilsludge mixture of $2.4 \times 10^{-5} \mathrm{~m} \mathrm{~s}^{-1}$ to $5.4 \times 10^{-6} \mathrm{~m} \mathrm{~s}^{-1}$, figure 6. Feitosa (2009) also showed that the void volume was reduced with sewage sludge application for the same weight dry density of soil-sludge mixture.

Table 4. Average results obtained by chemical analysis of the effluents collected 15, 30, 45, and 60 days after leaching

\begin{tabular}{|c|c|c|c|c|c|c|c|c|}
\hline \multirow{2}{*}{ Attribute } & \multicolumn{4}{|c|}{$1^{\text {st }}$ leaching period (15 days) } & \multicolumn{4}{|c|}{$2^{\text {st }}$ leaching period (30 days) } \\
\hline & 0 & 25 & 50 & 75 & 0 & 25 & 50 & 75 \\
\hline & & & & & $\mathrm{Mg} \mathrm{ha}^{-1}$ & & & \\
\hline Water pH (1:2.5) & 8.05 & 7.45 & 7.84 & 7.74 & 7.22 & 6.92 & 6.32 & 6.82 \\
\hline $\mathrm{EC} \mu \mathrm{S}$ & 2.40 & 741.00 & 760.00 & 620.00 & 407.00 & 774.33 & 1311.00 & 1626.00 \\
\hline $\mathrm{P}\left(\mathrm{mg} \mathrm{kg}^{-1}\right)$ & 27.67 & 26 & 24.33 & 26.67 & 18.33 & 21.33 & 24.00 & 21.22 \\
\hline $\mathrm{Na}^{+}\left(\mathrm{mg} \mathrm{kg}^{-1}\right)$ & 138.67 & 137 & 119.33 & 119.67 & 30.00 & 35.00 & 41.33 & 45.00 \\
\hline $\mathrm{Cu}^{2+}\left(\mu \mathrm{g} \mathrm{mL}^{-1}\right)$ & 0.05 & 0.05 & 0.03 & 0.16 & 0.13 & 0.05 & 0.08 & 0.32 \\
\hline $\mathrm{Zn}^{2+}\left(\mu \mathrm{g} \mathrm{mL}^{-1}\right)$ & 0.05 & 0.16 & 0.03 & 0.03 & 0.10 & 0.09 & 0.09 & 0.15 \\
\hline $\mathrm{Fe}^{2+}\left(\mu \mathrm{g} \mathrm{mL}^{-1}\right)$ & 1.65 & 1.17 & 1.57 & 2.53 & 9.45 & 0.53 & 1.72 & 1.68 \\
\hline \multirow[t]{2}{*}{$\mathrm{Cd}^{2+}\left(\mu \mathrm{g} \mathrm{mL}^{-1}\right)$} & 0.21 & 0.11 & 0.99 & 0.01 & 0.09 & 0.13 & 0.07 & 0.03 \\
\hline & \multicolumn{4}{|c|}{$3^{\text {st }}$ leaching period (45 days) } & \multicolumn{4}{|c|}{$4^{\text {st }}$ leaching period (60 days) } \\
\hline Water $\mathrm{pH}(1: 2.5)$ & 6.69 & 6.61 & 6.70 & 6.67 & 6.66 & 6.68 & 6.67 & 6.67 \\
\hline $\mathrm{EC} \mu \mathrm{S}$ & 353.33 & 1466.00 & 2233.33 & 3213.33 & 149.11 & 324.67 & 732.00 & 1206.67 \\
\hline $\mathrm{P}\left(\mathrm{mg} \mathrm{kg}^{-1}\right)$ & 22.19 & 22.47 & 21.96 & 22.20 & 22.21 & 22.12 & 22.18 & 22.17 \\
\hline $\mathrm{Na}^{+}\left(\mathrm{mg} \mathrm{kg}^{-1}\right)$ & 37.26 & 38.01 & 36.91 & 37.39 & 37.44 & 37.24 & 37.36 & 37.35 \\
\hline $\left.\mathrm{Cu}^{2+}(\mu \mathrm{g} \mathrm{mL})^{-1}\right)$ & 0.03 & 0.11 & 0.08 & 0.06 & 0.05 & 0.07 & 0.04 & 0.08 \\
\hline $\mathrm{Zn}^{2+}\left(\mu \mathrm{g} \mathrm{mL}^{-1}\right)$ & 0.08 & 0.14 & 0.07 & 0.13 & 0.06 & 0.06 & 0.07 & 0.22 \\
\hline $\mathrm{Fe}^{2+}\left(\mu \mathrm{g} \mathrm{mL}^{-1}\right)$ & 7.65 & 0.88 & 0.72 & 0.73 & 1.68 & 0.08 & 0.60 & 0.27 \\
\hline $\mathrm{Cd}^{2+}\left(\mu \mathrm{g} \mathrm{mL}^{-1}\right)$ & 0.25 & 0.06 & 0.02 & 0.03 & 0.04 & 0.02 & 0.02 & 0.04 \\
\hline
\end{tabular}




\section{CONCLUSIONS}

1. Sewage sludge application induced changes in soil physical, chemical and microstructural attributes as follows: increase in the fractions $<0.005 \mathrm{~mm}$, increase in porosity, increase in surface moisture, and improvement in particle aggregation. On the other hand, the values of the apparent maximum dry unit weight decreased and the sand grains were progressively coated by smaller sludge particles.

2 . The use of increasing sewage sludge doses reduced $\mathrm{pH}$ values and increased the levels of $\mathrm{EC}, \mathrm{P}$, $\mathrm{K}^{+}, \mathrm{Na}^{+}, \mathrm{Mg}^{2+}, \mathrm{Zn}^{2+}$, and $\mathrm{Fe}^{2+} . \mathrm{Al}^{3+}$. Certain minerals were retained in the top soil but $\mathrm{N}$ was more frequently found at higher levels in the soil at the column base.

3. Sewage sludge doses increasing from 25 to $75 \mathrm{Mg} \mathrm{ha}^{-1}$ induced a small reduction in hydraulic conductivity of soil-sludge mixture.

4. The leaching levels of potentially toxic elements from sewage sludge treatments causes no harm to the environment.

\section{ACKNOWLEDGEMENTS}

The authors are indebted to the International Federation of Catholic Universities and the National Council for Scientific and Technological Development $(\mathrm{CNPq})$ for the financial support of this research.

\section{LITERATURE CITED}

ASSOCIAĈ̃O BRASILEIRA DE NORMAS TÉCNICAS ABNT. NBR 7181: Solos - análise granulométrica conjunta. Rio de Janeiro, 1984a.

ASSOCIAÇÃO BRASILEIRA DE NORMAS TÉCNICAS ABNT. NBR 6508: Massa específica dos grãos. Rio de Janeiro, 1984b.

ASSOCIAÇÃO BRASILEIRA DE NORMAS TÉCNICAS ABNT. NBR 6459: Solos - determinação do limite de liquidez. Rio de Janeiro, 1984c.

ASSOCIAÇÃO BRASILEIRA DE NORMAS TÉCNICAS ABNT. NBR 7180: Solos - determinação do limite de plasticidade. Rio de Janeiro, 1984d.

ASSOCIAÇÃO BRASILEIRA DE NORMAS TÉCNICAS . ABNT. NBR 6467: Solo - determinação dos grãos do solo que passam na peneira de $4,8 \mathrm{~mm}$, determinação da massa específica aparente. Rio de Janeiro, 1986a.

ASSOCIAÇÃO BRASILEIRA DE NORMAS TÉCNICAS ABNT. NBR 7182: Solos - ensaio de compactação. Rio de Janeiro, 1986b.
BARBOZA, R.S.L. Influência do lodo de esgoto na nodulação e no desenvolvimento do Caupi.. Recife, Universidade Católica de Pernambuco, 2007. 84p. (Tese de Mestrado)

BREWER, R. Fabric and mineral analysis of soils. New York, Robert E. Krieger Publications, 1976. 482p.

CAVALLARO, N.; PADILLA, N. \& VILLARRUBIA, J. Sewage sludge effects on chemical properties of acid soils. Soil Sci., 156:63-70, 1993.

EMPRESA BRASILEIRA DE PESQUISA AGROPECUÁRIA EMBRAPA. Centro Nacional de Pesquisas de Solos. Manual de métodos de análise de solo. Rio de Janeiro, 1997. 212p.

FEITOSA, M.C.A. Lodo de esgoto: Aplicações na engenharia.. Recife, Universidade Católica de Pernambuco, 2009. 120p. (Tese de Mestrado)

FERREIRA, S.R.M. Colapso e expansão de solos naturais não saturados devidos à inundação. Rio de Janeiro, Universidade Federal do Rio de Janeiro, 1995. 379p. (Tese de Doutorado)

JOLLIFFE, I.T. Principal component analysis. 2.ed. New York, Springer-Verlag, 2002. 502p.

LOPES, M.A.J. Incorporação de lodo de esgoto e seus efeitos sobre alguns atributos do solo cultivado com Rabanetes. Recife, Universidade Católica de Pernambuco, 2008. 99p. (Tese de Mestrado)

MELO, W.J. \& MARQUES, M.O. Potencial do lodo de esgoto como fonte de nutrientes para as plantas. In: BETTIOL, W. \& CAMARGO, O.A. Impacto ambiental do uso agrícola do lodo de esgoto. Jaguariúna, Embrapa Meio Ambiente, 2000. p.109-141.

MELO, W.J.; MARQUES, M.O.; SANTIAGO, G. \& CHELLI, R.A. Efeito de doses crescentes de lodo de esgoto sobre frações da matéria orgânica e CTC de um Latossolo cultivado com cana-de-açúcar. R. Bras. Ci. Solo, 18:449455,1994

OLIVEIRA F.C. \& MATTIAZZO, M.E. Mobilidade de metais pesados em um Latossolo Amarelo distrófico tratado com lodo de esgoto e cultivado com cana-de-açúcar. Sci. Agríc., 58:807-812, 2001

OLIVEIRA, F.C.; MATTIAZZO, M.E.; MARCIANO, C.R. \& ROSSETO, R. Efeitos de aplicações sucessivas de lodo de esgoto em Latossolo Amarelo distrófico cultivado com cana-de-açúcar: Carbono orgânico, condutividade elétrica, pH e CTC. R. Bras. Ci. Solo, 26:505-519. 2002.

OLIVEIRA, L.A.; MARTINS, F.P. \& PEDROSO, L.B. Estudo comparativo entre condutividade hidráulica e textura de latossolos arenosos na micro-bacia do Córrego Irapitinga, município de Ituiuba/MG. In: SIMPÓSIO BRASILEIRO DE GEOGRAFIA APLICADA, 13., Viçosa, MG, 2009. Anais... Viçosa, MG, Universidade Federal de Viçosa, 2009. CD ROM.

SANTOS, A.D. Estudo das possibilidades de reciclagem dos resíduos de tratamento de esgoto da Região Metropolitana de São Paulo. São Paulo, Universidade de São Paulo, 2003. 265p. (Tese de Mestrado) 
SILVA, J.E.; RESCK D.V.S. \& SHARMA, R.D. Alternativa agronômica para o biossólido produzido no Distrito Federal. I - Efeito na produção de milho e adição de metais pesados em Latossolo no cerrado. R. Bras. Ci. Solo, 26:487-495, 2002 .

SILVA, A. B. Planejamento experimental e modelagem estatística do efeito do uso de lodo em solos. Recife, Universidade Católica de Pernambuco, 2008. 54p. (Tese de Mestrado)

TEIXEIRA, R.S.; RODRIGUEZ, T.T.; BRANCO, C.J.M.C. \& SILVA, S.M.C.P. Caracterização de solo alterado em decorrência da interação solo lixiviado. In: CONGRESSO BRASILEIRO DE MECÂNICA DOS SOLOS E ENGENHARIA GEOTÉCNICA, 15., Gramado, 2010. Anais... Gramado, ABMS, 2010a. CD ROM.
TEIXEIRA, R.S.; CAMBIER, P.; DIAS, R.D.; PINESE J.P.P. \& JAULIN-SOUBET, A. Mobility of potentially harmful metals in Latossolos impacted by the municipal solid waste deposit of Londrina, Brazil. Appl. Geochem., 25:1-15, 2010 b.

TOME JR., J.B. Manual para interpretação de análise de solo. Guaíba, Agropecuária, 1997. 247p. 
